\title{
The Potential of Combined Curcuma xanthorrhiza Rhizome and Averrhoa blimbi Fruit Extract on Decreasing Blood Glucose Levels, Insulitis Degree and Liver Structure Repair of Diabetic Male Wistar Rats Streptozotocin Induced
}

\author{
Kartiawati Alipin ", Nurani Istiqamah, Annisa Maryani, Madihah \\ Department of Biology, Faculty of Mathematics and Natural Sciences, Universitas Padjadjaran, Jl. Raya Bandung Sumedang Km 21 \\ Jatinangor, 45363, Indonesia
}

\begin{abstract}
Curcuma xanthorrhiza Roxb. rhizomes and Averrhoa bilimbi L. fruits have been potential as anti-diabetic herbs. Diabetes mellitus (DM) is a metabolic disorder characterized by high blood glucose levels or hyperglycemia due to deficiency or ineffectiveness of insulin. The combined use of natural herb (polyherb) is expected to produce a holistic effect in maintaining health and treating disease. This study aims to determine the effectiveness and optimum dosage combination C. xanthorrhiza rhizomes and A. blimbi fruit extract as anti-diabetic herbs in decreasing blood glucose levels, improve pancreas histopathology and the liver structure repair of diabetic male Wistar rats induced by streptozotocin. Twenty-one rats were divided into eighteen diabetic and three nondiabetic rats. The diabetic rats were divided equally into six groups; treated with CMC 0.5\% (diabetic control), glibenclamide dosage $0.45 \mathrm{mg} / \mathrm{kg} \mathrm{bw}$ (reference), extract of C. xanthorrhiza dosage $17.5 \mathrm{mg} / \mathrm{kg}$ bw, extract of A. blimbi dosage $750 \mathrm{mg} / \mathrm{kg}$ bw, combined extract dosages 767.5 and $383.75 \mathrm{mg} / \mathrm{kg}$ bw for 21 constitutive days. The results showed that a higher dosage of combination extract $(767.5 \mathrm{mg} / \mathrm{kg} \mathrm{bw})$ that significantly lowered blood glucose levels $(54.86 \pm 34.61 \%)$ and improved the pancreas histopathology characterized by increasing number $(9.33 \pm 0.58)$ and diameter $(53.34 \pm 8.82)$ of Langerhans islet as well as decreasing insulitis degree compared to diabetic rats $(\mathrm{p}<0.05)$ and from treatment dosage $383.75 \mathrm{mg} / \mathrm{kg}$ bw could decrease the diameter of central vein and percentage necrotized cells of hepatocytes which significantly different with reference and diabetic control $(\mathrm{p}<0.05)$, and comparable with nondiabetic rats. In conclusion, the combined extracts were more effective than single extract to treat diabetic rats induced by streptozotocin.
\end{abstract}

Keywords: A. blimbi; C. xanthorrhiza; Diabetic; Insulitis; Liver histological; Rat

\section{INTRODUCTION}

Diabetes mellitus (DM) is a metabolic disorder characterized by high blood glucose levels or hyperglycaemic due to deficiency or ineffectiveness of insulin. Hyperglycaemic is associated with dysfunction or damage of pancreatic $\beta$ cells caused by free radicals, viral infections, autoimmune reactions in the form of antibody attack against $\beta$ cells, diabeto genic substances, glucose toxicity, obesity and genetic factors [1]. The body needed insulin to plays a role in facilitating the diffusion of glucose into the body cells, especially the liver, muscle, and adipose tissue.
Insulin also stimulates glycogenesis and inhibits glycogenolysis so that blood glucose levels can be controlled or normal [2]. The condition of diabetes can also be observed through pancreatic histopathology due to impaired $\beta$ cell function. Histopathology pancreatic model of diabetic animals that generally occur is the depletion of the size (atrophy) of endocrine cells on the island of Langerhans [3]. Abnormalities of insulin experienced by DM patients have an impact on metabolic disorders that occur in the liver. Liver damage complications such as glycogen deposits, *Correspondence to: Kartiawati Alipin, Department of Biology, Faculty of Mathematics and Natural Sciences, Universitas Padjadjaran, Jl. Raya
Bandung Sumedang Km 21 Jatinangor, 45363, Indonesia, Tel: 022 7796412; E-mail: kartiawati@unpad.ac.id

Received: August 19, 2019; Accepted: October 10, 2019; Published: October 17, 2019

Citation: Alipin K, Istiqamah N, Maryani A, Madihah (2019) The Potential of Combined Curcuma xanthorrhiza Rhizome and Averrhoa blimbi fruit extract on decreasing blood glucose levels, insulitis degree and liver structure repair of diabetic male Wistar rats streptozotocin induced. J Diabetes Metab 10:835. doi: 10.35248/2155-6156.19.10.835

Copyright: (C) 2019 Alipin K, et al. This is an open-access article distributed under the terms of the Creative Commons Attribution License, which permits unrestricted use, distribution, and reproduction in any medium, provided the original author and source are credited. 
nonalcoholic, steatohepatitis (NASH), fibrosis, cirrhosis, biliary disorders, cholestasis, cholelithiasis, and cholecystitis [4].

Treatment of DM patients is done by setting dietary patterns, using oral antidiabetic drugs (OAD), or insulin injections [5]. Side effects of synthetic drug use are relatively higher and cause dependence. Long-term use of one of the oral drugs of the DM class of sulfonylureas including glibenclamide has been known to induce hypoglycaemic in elderly, hepatic impairment, and renal impairment [6]. Efforts to reduce the dependence of OAD use, it is necessary to look for natural antidiabetic with minimal risk of side effects. Medicinal plants in Indonesia are known to be efficacious as a natural antidiabetic drug such as temulawak (Curcuma xanthorrhiza Roxb.) and belimbing wuluh (Averrhoa blimbi L.). Natural ingredients used in the treatment of natural antidiabetic include C. xanthorrhiza rhizome has been done by people in Tabalong South Kalimantan as well as the decoction of A. blimbi leaves [7]. The plant has antioxidant compounds to reduce oxidative stress due to hyperglycaemic conditions.

According to Cahyani [8], that the dosage $17.5 \mathrm{mg} / \mathrm{kg}$ bw of C. xanthorrhiza rhizome extract decreased the blood glucose level of alloxan-induced rats for 14 days of treatment is proportional to the metformin dosage $63 \mathrm{mg} / \mathrm{kg}$ bw. Similarly, Candra [6] which states that the extract of A. blimbi fruit dosage $750 \mathrm{mg} /$ $\mathrm{kg}$ bw was effective for decreasing blood glucose level in alloxaninduced rats for 28 days of treatment. Decreased blood glucose levels are suspected to be influenced by the activity of secondary metabolites of these plants such as flavonoids and saponins. Some types of flavonoids, especially quersetin in C. xanthorrhiza have been known as hepatoprotectors. The hepatoprotector activity is likely to occur because flavonoids can bind to free radicals and inhibit lipid peroxidation [5]. According to Khimmaktong [9], curcumin content as found in C. xanthorrhiza can improve, increase regeneration, and prevent complications of micro vascular tissue in diabetic liver until it reaches normal liver condition. Using two or more natural materials simultaneously is known to be very useful because it has a holistic effect on maintaining health and treating illness. Therapy uses a mixture of natural ingredients known as polyherb that therapy produces a synergistic effect of each compound contained therapeutic effect. Polyherb therapy is in accordance with pharmacological principles which are producing maximum efficiency with minimal side effects [10].

\section{MATERIALS AND METHODS}

Collection and extraction of plant materials A. blimbi fruits were collected from Arboretum, University of Padjadjaran in Jatinangor, Sumedang, Indonesia, whereas C. xanthorrhiza rhizomes were collected from Indonesian Medicinal and Aromatic Crops Research Institute, Manoko Lembang, Bandung, Indonesia. The samples were identified in Taxonomy Laboratory in the Department of Biology, Faculty of Mathematics and Natural Sciences, University of Padjadjaran. The samples were air-dried to a constant weight and blend to a coarse powder. The dried powder was soaked and macerated on 95\% ethanol for 72 hours and every 24 hours the macerate was collected. The macerate was then evaporated using a rotary evaporator, resulting in a paste extract.

\section{Experimental animals}

Research was carried out in the Laboratory of Biosystem, Department of Biology, Universitas Padjadjaran, Indonesia. Using twenty-one male rat (160-180 g), Wistar, eight weeks old. The rats were randomly divided into seven groups, 3 rats per group. They were housed in a standardized environmental condition and fed with piglet standard diets (CP-551, PT. Charoen Pokphand) and water which were given ad libitum. Animal care and handling conformed to accepted guidelines.

\section{Induction of diabetic and determination of blood glucose level}

After one week of acclimatization period, the animals fasted overnight, and their fasting blood glucose levels were determined using a glucometer, by collecting blood via the tail vein. Diabetic was induced by intraperitoneally injecting six rat groups with streptozotocin (STZ) $(60 \mathrm{mg} / \mathrm{kg} \mathrm{BW})$ that was freshly prepared in $10 \mathrm{mM}$ citrate buffer solution, $\mathrm{pH} 4.5$. Negative control rats were injected with citrate buffer. To prevent hypoglycaemic after STZ induction, the rats were supplemented with $10 \%$ sucrose solution for three days. Three days after the administration of STZ, the rats have fasted again and the blood was collected from their tail cut to determine their fasting glucose levels. Rats which have glucose level more than $200 \mathrm{mg} / \mathrm{dL}$ were categorized as diabetic and used for further experiments.

\section{Treatments of the extract}

The experiment was conducted with Completely Randomized Design, twenty-one rats were divided into eighteen diabetic and three nondiabetic rats (NC). The diabetic rats were divided equally into six groups; treated with CMC $0.5 \%$ (PC), glibenclamide dosage $0.45 \mathrm{mg} / \mathrm{kg} \quad$ bw (G), extract of C. xanthorrhiza rhizome dosage $17.5 \mathrm{mg} / \mathrm{kg}$ bw (T), extract of A. blimbi fruits dosage $750 \mathrm{mg} / \mathrm{kg}$ bw (BW), combined extract dosages 767.5 (TBW1) and $383.75 \mathrm{mg} / \mathrm{kg}$ bw (TBW2) for 21 constitutive days. On the $22 \mathrm{nd}$ days, after an overnight fast, the animals were weighed and sacrificed by cervical dislocation, and necropsies were done on them. Furthermore, pancreatic and liver were isolated from the rats and weighed, then examined for their morphology, i.e., the colours and textures. Last, the organs were preserved in Bouin's solution for histopathological examination.

\section{Parameters observed}

The observed parameters included fasting blood glucose levels of rats on days $0,8,15$ and 22 , as well as pancreatic histopathology features of the number, diameter, and degree of insulin in the island of Langerhans. Morphology and histological observations of the liver were measuring the diameter of the central vein and percentage of necrotized cells of hepatocytes.

The percentage decrease in blood glucose levels (BGL) was calculated using a formula based on Jain et al. as follows: 
Decrease in BGL $=\frac{\text { BGL day 0 - BGL day } 22}{\text { BGL day } 0} \times 100 \%$

\section{Pancreatic and liver histopathology observation}

Histopathology examination was performed through morphometric analysis by assessing the number, diameter, and degree of insulin in the Langerhans islands was observed using an Olympus microscope.

Table 1: Classification of insulitis.

\begin{tabular}{ccc}
\hline Score & Parameter & Insulitis degree \\
\hline 0 & No inflammation & Normal \\
\hline 1 & Inflammation $\leq 25 \%$ & Mild insulitis \\
\hline 2 & Inflammation $25 \% \leq \mathrm{x}<80 \%$ & Medium insulitis \\
\hline 3 & Inflammation $80 \% \leq \mathrm{x}<100 \%$ & Severe insulitis \\
\hline 4 & Inflammation $100 \%$ & End stage insulitis \\
\hline
\end{tabular}

The number of Langerhans islands ( $\mathrm{n}$ ) on each preparation is calculated and expressed in units (n) of each pancreas network at 5 zones of magnification field 100 times. The diameter of the Langerhans islands was measured from five representative Langerhans Islands of each preparation (400 times magnification) and expressed in $\mu \mathrm{m}$ units. The degree of insulitis is calculated by the distribution of mononuclear cells around the islets of Langerhans pancreas. Assessment by looking at the degree of insulitis on Langerhans Island and in the surrounding area at 400 times magnification, consistently in 5 field-of-view zones, at least 5 Langerhans islands. The degree of insulitis classification according to Leiter presented in Table 1. Histological observations of the liver were performed under a microscope by measuring the diameter of central vein and percentage necrotized cells of hepatocytes in 5 different planes (four angles of the upper and lower and one center angle) using 400 times magnification with 1 replication.

\section{Data analysis}

Results were expressed as mean \pm standard deviation (S.D). Statistical significance was analyzed using one-way ANOVA followed by Duncan multiple range test. $P$ values less than 0.05 were considered significant. Score data of insulitis degree were analyzed using Kruskal-Wallis with 95\% confidence level.

\section{RESULTS AND DISCUSSION}

The effect of C. xanthorrhiza and A. blimbi extract on fasting blood glucose level are presented in Table 2. Average blood glucose level PC (induced by STZ $60 \mathrm{mg} / \mathrm{kg} \mathrm{bw}$ ) is in a range above $200 \mathrm{mg} / \mathrm{dL}$. It proves that STZ is capable of causing permanent hyperglycaemic conditions in animal experiments by causing damage to pancreatic $\beta$ cells due to necrosis [11].

Table 2: Average of percentage decrease of fasting blood glucose level of rats.

Blood glucose level (mg/dL)

Percentage decrease of glucose level (\%)

\begin{tabular}{|c|c|c|c|c|}
\hline \multirow[b]{2}{*}{ Treatments } & \multirow[b]{2}{*}{ Before treatment } & \multicolumn{2}{|c|}{ After treatment } & \multirow[b]{3}{*}{$-7,31 \pm 20,63^{\mathrm{ab}}$} \\
\hline & & Day-0 & Day-22 & \\
\hline $\mathrm{NC}$ & $102,33 \pm 28,71$ & $113,33 \pm 6,66$ & $121,33 \pm 22,9$ & \\
\hline $\mathrm{PC}$ & $79 \pm 3,60$ & $445,67 \pm 99,48$ & $485 \pm 104,76$ & $-9,27 \pm 7,79^{\mathrm{a}}$ \\
\hline G & $99,67 \pm 12,01$ & $421,67 \pm 59,09$ & $284,67 \pm 43,59$ & $31,57 \pm 13,95^{\mathrm{bc}}$ \\
\hline $\mathrm{T}$ & $93,33 \pm 21,54$ & $528,33 \pm 49,54$ & $447 \pm 123,48$ & $19,49 \pm 15,35^{a b c}$ \\
\hline BW & $77,33 \pm 6,81$ & $574,33 \pm 22,28$ & $479,67 \pm 109,45$ & $15,29 \pm 18,57^{\mathrm{ab}}$ \\
\hline TBW1 & $102,33 \pm 7,02$ & $546 \pm 20,78$ & $243,33 \pm 182,25$ & $54,86 \pm 34,61^{\mathrm{c}}$ \\
\hline TBW2 & $64 \pm 5,56$ & $550 \pm 49,50$ & $233,33 \pm 109,21$ & $56,20 \pm 23,20^{c}$ \\
\hline
\end{tabular}

Note: Different letters in a column indicate that there is a marked difference between treatments based on Duncan's multiple-range test ( $<<0.05)$.

Average blood glucose level PC induced by STZ $60 \mathrm{mg} / \mathrm{kg}$ bw is in the BGL range above $200 \mathrm{mg} / \mathrm{dL}$. It proves that STZ is capable of causing permanent hyperglycemic conditions in animal experiments by causing damage to pancreatic $\beta$ cells due to necrosis as described by Szkudelski [11]. Treatment of extracts can lower blood glucose levels in animal models of diabetes. The average percentage of decrease of blood glucose level of C. xanthorrhiza treatment, A. blimbi, high dosage combination and low dosage combination were $19,49 \pm 15,35 ; 15.29 \pm 18.57$; $54.86 \pm 34.61$; and $56.20 \pm 23.20 \%$. ANOVA test results 
obtained value Fcount (4.930)>Ftable (2.85), this indicates that the treatment can lower blood glucose levels significantly. Based on Duncan's multiple assay, the decrease of blood glucose level in the combination treatment of TBW1 and TBW2 extracts was significantly different from the treatment of PC $(p<0.05)$. The average percentage of decreased blood glucose levels by the combination of these extracts was not significantly different from the treatment of glibenclamide antidiabetic drugs, but significantly different from the single extract treatment $(\mathrm{p}<0.05)$.

The combination of high dosage extract $(767,5 \mathrm{mg} / \mathrm{kg} \mathrm{bw})$ decreased percentage of blood glucose level 54,86 $\pm 34,61 \%$ and low dosage $(383,75 \mathrm{mg} / \mathrm{kg} \mathrm{bw})$ decreased blood glucose level equal to $56,20 \pm 23,20 \%$. The effectiveness of the combination extracts in reducing blood glucose level is thought to be caused by the mutual interaction between the bioactive compounds contained in each extract in the form of flavonoids, curcuminoids and saponins. Bioactive compounds contained in C. xanthorrhiza and A. blimbi are flavonoids that have activity as antioxidants that can lower blood glucose levels by donating one of the electrons to free radical compounds such as nitric oxide (NO), superoxide $\left(\mathrm{O}_{2}^{-}\right)$, hydrogen peroxide $\left(\mathrm{H}_{2} \mathrm{O}_{2}\right)$, and hydroxyl $\left(\mathrm{OH}^{-}\right)$. Through this mechanism, flavonoids can decrease the reaction of the formation of reactive oxygen compounds and prevent oxidation caused by the increase of radical compounds [12]. In addition, the role of flavonoids as a natural antioxidant is thought to be capable of handling complications due to hyperglycemia such as glucose autoxidation, protein glycation and lipid peroxidation [13].

According to Zhang et al. [14] bioactive compounds that also play a role in the decrease in blood glucose level is curcuminoids contained in C. xanthorrhiza extract. Curcuminoids significantly suppresses elevated blood glucose levels by activating peroxisome proliferators activated receptors (PPAR- $\gamma$ ) whose mechanisms work similarly to insulin sensitizing drugs by preventing lipid peroxidation and increasing the production of antioxidant enzymes such as superoxide dismutase and catalase. Bioactive compounds that also play a role in lowering blood glucose levels are saponins contained in extract A. blimbi, so that saponin allegedly also play a role in improving the ability of therapeutic combination of C. xanthorrhiza extract and A. blimbi as herbal antidiabetic.

The data average of the number, diameter, and degree of insulin in the island of Langerhans presented in Table 3.

Table 3: Histopathology observation rate of pancreatic rats.

\begin{tabular}{|c|c|c|c|c|}
\hline \multirow[b]{2}{*}{ Treatments } & \multirow{2}{*}{$\begin{array}{l}\text { Average number } \\
\text { Langerhans }\end{array}$} & \multirow{2}{*}{$\begin{array}{l}\text { Average diameter } \\
\text { Langerhans }(\mu \mathrm{m})\end{array}$} & \multicolumn{2}{|c|}{ Insulitis } \\
\hline & & & Score (Average \pm SD) & Degree \\
\hline $\mathrm{NC}$ & $10,67 \pm 1,15^{\mathrm{d}}$ & $55,07 \pm 10,55^{c}$ & $0,06 \pm 0,26$ & Normal \\
\hline PC & $5 \pm 1,00^{\mathrm{a}}$ & $28,04 \pm 1,88^{\mathrm{a}}$ & $1,87 \pm 0,63$ & Medium insulitis \\
\hline G & $5,33 \pm 1,15^{\mathrm{ab}}$ & $37,96 \pm 7,98^{a b}$ & $1,33 \pm 0,72$ & Mild insulitis \\
\hline $\mathrm{T}$ & $7 \pm 1,73^{\mathrm{abc}}$ & $36,86 \pm 4,05^{\mathrm{ab}}$ & $1,07 \pm 0,25$ & Mild insulitis \\
\hline BW & $6,33 \pm 2,08^{a b c}$ & $46,27 \pm 5,12^{b c}$ & $1 \pm 0,75$ & Mild insulitis \\
\hline TBW1 & $9,33 \pm 0,58^{\mathrm{cd}}$ & $53,34 \pm 8,82^{c}$ & $0,73 \pm 0,45$ & Mild insulitis \\
\hline TBW2 & $8 \pm 2,00^{\mathrm{bcd}}$ & $49,89 \pm 8,94^{b c}$ & $1,07 \pm 0,45$ & Mild insulitis \\
\hline
\end{tabular}

Note: Different letters in a column indicate that there is a marked difference between treatments based on Duncan's multiple-range test $(\mathrm{p}<0.05)$. Score data of insulitis degree were analyzed using Kruskal-Wallis with $95 \%$ confidence level.

The result of ANOVA test mean that the number of Langerhans Island obtained Fcount $(5,957)$ and Langerhans island diameter obtained Fcount $(5,461)>$ Ftable $(2,85)$. Duncan's multiple assay results that the mean and normal diameter of Langerhans island was significantly different from that of the diabetic model and glibenclamide treatment $(p<0.05)$. The combined treatment of high-dosage extract TBW1 was also significantly different from the diabetic model animals $(p<0.05)$ and was not significantly different from the normal. These results indicate pancreatic histopathology improvement by a combination of extracts of an increase in the number and diameter of the Langerhans islands.
Analysis of the degree of insulitis among treatments using the Kruskal-Wallis test showed that there was a difference between treatments $(p<0.05)$. Therefore, it was followed by MannWhitney test which gave the result that the diabetic model of animals insulitis degree score was significantly different with normal $(p<0.05)$. The degree of insulin treatment of combination extracts of TBW1 and TBW2 was significantly different from the diabetic model animals, although significantly different from normal $(p<0.05)$. These results suggest that has improvement of histopathology pancreatic by inhibits inflammation as evidenced by decreased degrees of insulitis even though it has not reached normal conditions. 
Pancreatic histopathology improvement ability is suspected to be influenced by the content of antioxidant flavonoids and curcuminoids that support each other in a combination of $\mathrm{C}$. xanthorrhiza rhizome extract and A. blimbi fruit. Flavonoids and curcuminoids attack free radicals by activating endogenous cellular antioxidants $\beta$ superoxide dismutase (SOD) and Catalase (CAT). SOD can convert free radicals into stable hydrogen peroxide $\left(\mathrm{H}_{2} \mathrm{O}_{2}\right)$, which is further detoxified by CAT to water $\left(\mathrm{H}_{2} \mathrm{O}\right)$ and oxygen so that the membranes and tissues are protected $[13,14]$.

The ability of pancreatic histopathology repair by a combination extracts is thought to be caused by the synergistic effect of the bioactive compounds in each extract. The ability of flavonoids and curcuminoids not only as antidiabetic, but also act as antiinflammatory by inhibiting the process of inflammation of insulitis. The anti-inflammatory mechanism of flavonoid compounds by inhibition of TNF- $\alpha$ (Tumor Necrosis Factor) and nitric oxide by lipopolysaccharide from activated macrophages. TNF- $\alpha$ suppression is suspected by inhibition of NF $\kappa B$ activation (Nuclear Factor Kappa $\beta$ ). TNF- $\alpha$ inhibition occurs in post transcriptional phase, while inhibition of inducible nitric oxide synthase in the transcription phase. Inhibition of $N F \kappa B$ activation would weaken the autoimmune response and inflammatory response, the results of this study inhibit the process of inflammation of the Langerhans islands (insulitis) [15].

\section{Effect of treatments on relative weight of liver}

The relative liver weight showed the percentage of liver-to-body weight at the end of the treatment period (Table 2). The result demonstrated that treatment of $60 \mathrm{mg} / \mathrm{kg} \mathrm{BW} \mathrm{STZ} \mathrm{(PC),} \mathrm{the}$ single and the combined extracts of C. xanthorrhiza rhizomes and A. blimbi fruit (T, BW, TBW1, TBW2), as well as 0.45 $\mathrm{mg} / \mathrm{kg} \mathrm{BW}$ glibenclamide (Reference) significantly increased the relative liver weight of compared with the negative control (NC) ( $\mathrm{p}<0.05$ ). The treatment with $767.5 \mathrm{mg} / \mathrm{kg}$ BW combined extract of C. xanthorrhiza rhizomes and A. blimbi fruit (TBW1) result in the highest relative weight of the liver.

\section{Effect of treatments on liver morphology}

The aim of the morphological examination was to evaluate the effect of the treatments on the color and texture of the liver (Figure 1). The result showed that treatment with $60 \mathrm{mg} / \mathrm{kg} \mathrm{BW}$ STZ dosage (PC), single and combined extracts of C. xanthorrhiza rhizomes and A. blimbi fruit (T, BW, TBW1, TBW2), as well as $0.45 \mathrm{mg} / \mathrm{kg}$ bw glibenclamide (reference), did not caused difference in the liver morphology compared with the NC group (Table 4).

Table 4: Mean of relative weight of liver after 21 days of treatment.

\begin{tabular}{|c|c|c|c|}
\hline ID & Body weight $(\mathrm{g})$ & Liver weight (g) & Relative weight of liver (\%) \\
\hline $\mathrm{NC}$ & $244,67 \pm 0,082$ & $10,37 \pm 0,029$ & $4,25 \pm 3,155^{\mathrm{a}}$ \\
\hline PC & $179 \pm 2,031$ & $9,66 \pm 1,087$ & $5,39 \pm 4,521^{\text {cde }}$ \\
\hline $\mathrm{T}$ & $173,33 \pm 1,003$ & $8,16 \pm 3,010$ & $4,71 \pm 4,052^{\mathrm{ab}}$ \\
\hline BW & $172,33 \pm 0,012$ & $9,06 \pm 0,045$ & $5,27 \pm 1,365^{\mathrm{bcd}}$ \\
\hline TBW1 & $186,67 \pm 1,007$ & $10,77 \pm 2,441$ & $5,74 \pm 4,622 \mathrm{~d}^{\mathrm{e}}$ \\
\hline TBW2 & $208 \pm 0,054$ & $10,4 \pm 0,044$ & $5,00 \pm 1,815^{b c}$ \\
\hline G & $177 \pm 0,034$ & $10,57 \pm 2,041$ & $5,97 \pm 4,092^{\mathrm{e}}$ \\
\hline
\end{tabular}

Note: The value is expressed as mean \pm standard deviation $(n=3)$. Data were analyzed using one-way ANOVA followed by Duncan multiple range test. Difference alphabet in the same column showed P values less than 0.05 and considered significant

The results showed that there was a significant effect on the liver, due to the toxic effects of streptozotocin resulting in hypoinsulinemia and reduced lipoprotein excretion from the liver [16]. Hypoinsulinemia can reduce the activity of the enzyme Lipoprotein Lipase (LPL), causing triglyceride (TG) deposits in the liver. This condition triggers a heavy increase in the liver with a weight loss of test animals so that it can increase the relative weight of the liver.

The relative weight of diabetic animal liver which has been given C. xanthorrhiza extract dosage $17.5 \mathrm{mg} / \mathrm{kg}$ bw $(\mathrm{T})$ is close to the relative weight of normal non-diabetic liver (NC). Thus, the treatment of single extract of C. xanthorrhiza is suspected to have the highest hepatoprotector activity among other extract treatments because it contains curcumin compounds which can improve, enhance regeneration, and withstand complications of diabetic liver tissue [9]. The combination of C. xanthorrhiza extract and A. blimbi dosage $383.75 \mathrm{mg} / \mathrm{kg}$ bw (TBW2) can still be said to have a hepatoprotector effect when compared with glibenclamide treatment dosage $0.45 \mathrm{mg} / \mathrm{kg}$ bw $(\mathrm{G})$ although the activity is not as good as the treatment of Curcuma extract in influencing the weight relatively liver. 


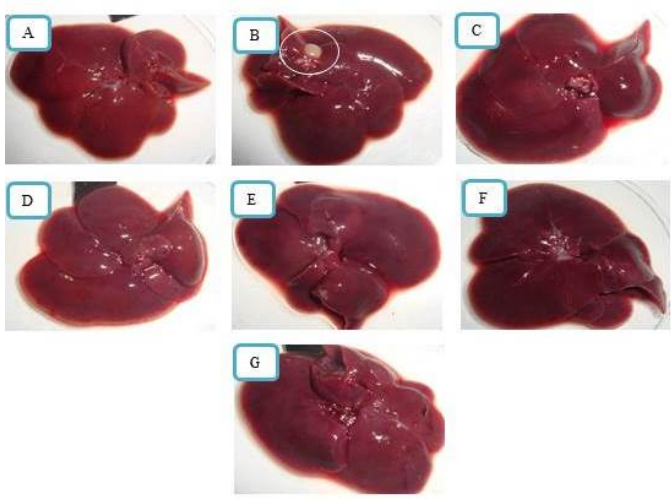

Figure 1: Morphology of liver after treatment for 21 days. Note: A. NC, B. PC, C. T, D. BW, E. TBW1, F. TBW2, G. Reference (G).

Improvements to diabetic liver disorders can be identified by macroscopic observation. The opinion of Robins and Kumar which states that normal liver has a flat and smooth surface and is brownish red. Broken liver has a non-smooth surface and spots, and discoloration becomes pale. Macroscopic changes in liver positive control (PC) are thought to be due to conditions of hypoinsulinemia, impaired fat metabolism, increased lipid peroxidation, and free radicals triggered by streptozotocin.

\section{Effect of treatment on liver histopathology}

The histopathological examinations of liver included measurement of central vein diameter and percentage necrotized cells of hepatocytes (Figure 2, Table 5).
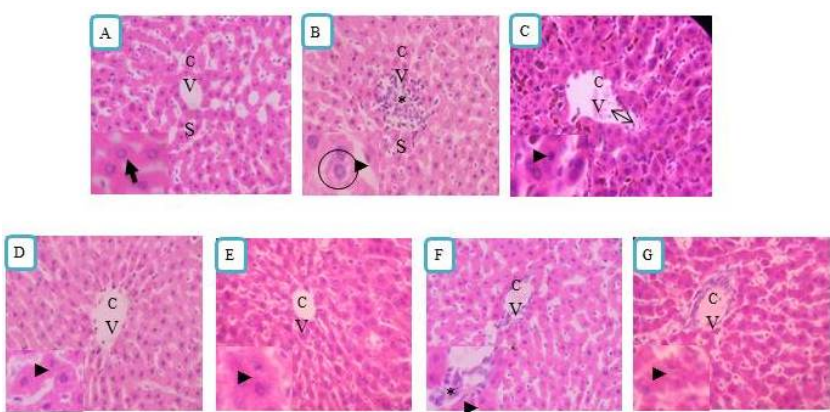

Figure 2: Photomicrograph of histological cross section of liver after treatment for 21 consecutive days. Heamatoxylin-Eosin stain. Note: A. NC, B. PC, C. T, D. BW, E. TBW1, F. TBW2, G. Reference. C: Central vein; : Necrotized cells hepatocytes.

Table 5: Histopathological measurement of liver after 21 days treatment.

\begin{tabular}{ccc}
\hline ID & Central vein diameter $(\mu \mathrm{m})$ & Number of necrotized cells hepatocytes $(\%)$ \\
\hline NC & $18,57 \pm 3.15^{\mathrm{a}}$ & $18,02 \pm 0,40^{\mathrm{a}}$ \\
\hline PC & $29,89 \pm 4,37^{\mathrm{c}}$ & $31,96 \pm 3,33^{\mathrm{c}}$ \\
\hline T & $19,56 \pm 4,05^{\mathrm{a}}$ & $23,62 \pm 2,55^{\mathrm{b}}$ \\
\hline BW & $21,75 \pm 6,81^{\mathrm{ab}}$ & $23,32 \pm 1,82^{\mathrm{b}}$ \\
\hline TBW1 & $25,05 \pm 4,62^{\mathrm{abc}}$ & $22,39 \pm 1,42^{\mathrm{b}}$ \\
\hline TBW2 & $20,55 \pm 5,60^{\mathrm{a}}$ & $21,67 \pm 2,81^{\mathrm{a}}$ \\
\hline G & $28,94 \pm 3,56^{\mathrm{bc}}$ & $30,18 \pm 1,54^{\mathrm{c}}$ \\
\hline
\end{tabular}

Note: The value is expressed as mean \pm standard deviation $(n=3)$. Data were analyzed using one-way ANOVA followed by Duncan multiple range test. Difference alphabet in the same column showed P values less than 0.05 and considered significant

The results showed normal conditions in the macroscopic liver treatment of glibenclamide dosage of $0.45 \mathrm{mg} / \mathrm{kg}$ bw $(\mathrm{G}), \mathrm{C}$. xanthorrhiza extract dosage of $17.5 \mathrm{mg} / \mathrm{kg}$ bw (T), A. blimbi extract dosage of $750 \mathrm{mg} / \mathrm{kg}$ bw (BW), and combination of C. xanthorrhiza extract and A. blimbi dosage 767.5 (TBW1) \& $383.75 \mathrm{mg} / \mathrm{kg}$ bb (TBW2), this shows normal conditions at the macroscopic level while microscopic observation of liver histology is needed to determine the level of improvement of polyherbal combination therapy with C. xanthorrhiza extract and A. blimbi on diabetic liver.

The percentage of hepatocyte necrosis in the negative control (NC) was significantly different $(p<0.05)$ on the percentage of hepatocyte necrosis in positive control (PC) which had been induced by streptozotocin. Percentage of hepatocyte necrosis in C. xanthorrhiza extract treatment dosage $17.5 \mathrm{mg} / \mathrm{kg}$ bw (T), A. blimbi extract dosage $750 \mathrm{mg} / \mathrm{kg}$ bw (BW), combination of C. xanthorrhiza extract and A. blimbi dosage $767.5 \mathrm{mg} / \mathrm{kg}$ bw (TBW1) and $383.75 \mathrm{mg} / \mathrm{kg}$ bw (TBW2) had significantly different results $(\mathrm{p}<0.05)$ on positive control $(\mathrm{PC})$ and was significantly different $(\mathrm{p}<0.05)$ against glibenclamide treatment at $0.45 \mathrm{mg} / \mathrm{kg}$ bw $(\mathrm{G})$. This condition shows that the use of herbal plants as antidiabetic has a smaller risk of liver damage than the oral drug glibenclamide. The antioxidant activity of the combination of C. xanthorrhiza extract and A. blimbi dosage of $383.75 \mathrm{mg} / \mathrm{kg} \mathrm{bw}$ (TBW2) is thought to originate from the interaction of the substance curcumin in C. xanthorrhiza, 
flavonoids, and saponins in A. blimbi. According to the other research Alipin (2017), that the treatment combined extract of C. xanthorrhiza rhizome and A. blimbi fruit at dose of 383,75 $\mathrm{mg} / \mathrm{kg}$ BW could improve histological damages of kidney as indicated by the decreasing of the glomerular diameter, Bowman space width, and the percentage of necrotized proximal tubules in diabetic rats induced by streptozotocin.

The combination of C. xanthorrhiza extract and A. blimbi dosage $767.5 \mathrm{mg} / \mathrm{kg}$ bw (TBW1) showed no improvement in the structure of diabetic rat liver, this may be due to the dosage of the combination of the two extracts is too high so that the active substance no longer acts as an herbal therapy. According to Wahyono, the use of traditional plants in treatment with dosage that exceed standards can be toxic.

\section{CONCLUSION}

The results of this study showed that a higher dosage of combination extract $(767.5 \mathrm{mg} / \mathrm{kg} \mathrm{bw})$ that significantly decrease blood glucose levels $(54.86 \pm 34.61 \%)$ and improved the pancreas histopathology characterized by increasing number $(9.33 \pm 0.58)$ and diameter $(53.34 \pm 8.82)$ of Langerhans islet as well as decreasing insulitis degree. However from a lower dosage of combination extract $(383.75 \mathrm{mg} / \mathrm{kg} \mathrm{bw})$ could decrease the diameter of central vein and percentage necrotized cells of hepatocytes which significantly different with reference and diabetic control $(\mathrm{p}<0.05)$, and comparable with nondiabetic rats. In conclusion, the combined extracts of C. xanthorrhiza rhizome and A. blimbi fruits were more effective than single extract to treat diabetic rats induced by streptozotocin.

\section{ACKNOWLEDGEMENTS}

This research was supported by Directorate of Research, Technology and Higher Education of the Republic of Indonesia. In this opportunity, we gratefully acknowledge the financial support of PUPT budget year 2017 \& 2018.

\section{REFERENCES}

1. Robertson RP. Chronic Oxidative Stress As A Central Mechanism For Glucose Toxicity In Pancreatic Islet B Cells In Diabetes. J Biol Chem. 2004;279: 41.

2. Sherwood L. Fisiologi manusia dari sel ke sistem. Ed. 2. Terj. dari Human physiology from cells to systems, oleh Brahm U. Pendit. Jakarta: Penerbit Buku Kedokteran EGC.2001.
3. Chang-Chen KJ, Mullur R, Bernal-Mizrachi E. $\beta$-cell failure as a complication of diabetes. Rev Endocr Metab Disord. 2008;(9): 329-343.

4. Rosman AS, Paronetto F, Galvin K, Williams RJ, Lieber CS. Hepatitis $\mathrm{C}$ virus antibody in alcoholic patients: Association with the presence of portal and/or lobular hepatitis. Arch Intern Med. 1993; 153:965-969.

5. Yuliana D, Tangking W. Reduction in Blood Glucose Levels and Hyperflycemic Kupffer Cell Counts After Giving Dekok Leaves of Salam. Veterinary Journal. 2014:15(4):541-547.

6. Candra S, Kusmiyati DK, Wiyoko YLA. Effect of fruit extract of Belimbing Wuluh (Averrhoa bilimbi L.) on reduction of blood glucose levels of Wistar Rats induced by alloxan. Jurnal Kedokteran Diponegoro.2012;1:(1).

7. Yuliatiningrum LR. Decreased Effect of Blood Glucose Levels on Ethyl Acetate Extract of Wuluh Starfruit (Averrhoa bilimbi L.) on Glucose-Loaded Male Rabbits. [Essay]. Surakarta: Faculty of Pharmacy Muhamma University in Surakarta. 2008.

8. Cahyani MN. Effect of ethanol extract ginger rhizome (Curcuma xanthorrizha Roxb.) against blood glucose levels of white rats (Rattus norvegicus) alloxan -induced wistar strains. [Hon. Thesis]. Universitas Tanjungpura, Pontianak.2014.

9. Khimmaktong W, Hattaya P, Busaba P, Vipavee A. Study of Curcumin on Microvasculature Characteristic in Diabetic Rat's Liver as Revealed by Vascular Corossion Cast/Scanning Electron Microscope (SEM) Technique. Journal of the Medical Association of Thailand. 2012;95:133-141.

10. Ebong PE, Atangwho IJ, Eyong EU, Egbung GE. The Antidiabetic Efficacy of Combined Extracts from two continental parts: Azadirachta indica (A. Juss) and Vernonia amygdalina (Del.). Agri Biol J N Am. 2008;3:4:239-244.

11. Szkudelski T. The mechanism of alloxan and streptozotocin action in $\beta$ cells of the rat pancreas. Physiol Res. 2001;50:536-554.

12. Mshelia DS. Role of free radical in pathogenesis of diabetes nephropathy. Ann Afr Med. 2004;3:55-62.

13. Winarsi H. Natural Antioxidants and Free Radicals; Potential and Application in Health. Yogyakarta: Kanisius Publisher. 2007.

14. Zhang D, Fu M, Gao S, Liu J. Curcumin and Diabetes: A Systematic Review. J Evid Based Complementary Altern Med. 2013.

15. Dewi M, Wijaya I, Wijayahadi N. Garlic Extract (Allium sativum) and Insulin Expression and Degrees of Pancreatic Insulitis in Streptozotocin-induced Sprague-Dawley Mice. M Med Indones. 2011;2:45.

16. Zafar M, Naqvi SN, Ahmed M, Kaimkhani ZA. Altered kidney morphology and enzymes in streptozotocin induced diabitc rats. Intl J Morphol. 2009;27 (3):783-790. 